Article

\title{
Tungsten carbide-reduced graphene oxide intercalation compound as co-catalyst for methanol oxidation
}

\author{
Meiqin Shi, Wentian Zhang, Yingying Li, Youqun Chu, Chun'an Ma* \\ State Key Laboratory Breeding Base of Green Chemistry-Synthesis Technology, College of Chemical Engineering, Zhejiang University of Technology, \\ Hangzhou 310032, Zhejiang, China
}

\section{A R T I C L E I N F O}

Article history:

Received 8 June 2016

Accepted 25 August 2016

Published 5 November 2016

\section{Keywords:}

Tungsten carbide-reduced

graphene oxide

Intercalation compound

Thiourea

Anchoring

Methanol oxidation

\begin{abstract}
A B S T R A C T
Highly dispersed tungsten carbide (WC) nanoparticles (NPs) sandwiched between few-layer reduced graphene oxide (RGO) have been successfully synthesized by using thiourea as an anchoring and inducing reagent. The metatungstate ion, $\left[\mathrm{H}_{2} \mathrm{~W}_{12} \mathrm{O}_{40}\right]^{6-}$, is assembled on thiourea-modified graphene oxide (GO) by an impregnation method. The WC NPs, with a mean diameter of $1.5 \mathrm{~nm}$, are obtained through a process whereby ammonium metatungstate first turns to $\mathrm{WS}_{2}$, which then forms an intercalation compound with RGO before growing, in situ, to WC NPs. The Pt/WC-RGO electrocatalysts are fabricated by a microwave-assisted method. The intimate contacts between Pt, WC, and RGO are confirmed by X-ray diffraction, scanning electron microscope, transmission electron microscope, and Raman spectroscopy. For methanol oxidation, the Pt/WC-RGO electrocatalyst exhibited an electrochemical surface area value of $246.1 \mathrm{~m}^{2} / \mathrm{g}$ Pt and a peak current density of $1364.7 \mathrm{~mA} / \mathrm{mg} \mathrm{Pt}$, which are, respectively, 3.66 and 4.77 times greater than those of commercial $\mathrm{Pt} / \mathrm{C}$ electrocatalyst $\left(67.2 \mathrm{~m}^{2} / \mathrm{g} \mathrm{Pt}, 286.0 \mathrm{~mA} / \mathrm{mg} \mathrm{Pt}\right)$. The excellent CO-poisoning resistance and long-term stability of the electrocatalyst are also evidenced by CO stripping, chronoamperometry, and accelerated durability testing. Because Pt/WC-RGO has higher catalytic activity compared with that of commercial Pt/C, as a result of its intercalated structure and synergistic effect, less Pt will be required for the same performance, which in turn will reduce the cost of the fuel cell. The present method is facile, efficient, and scalable for mass production of the nanomaterials.
\end{abstract}

(C) 2016, Dalian Institute of Chemical Physics, Chinese Academy of Sciences. Published by Elsevier B.V. All rights reserved.

\section{Introduction}

Among the different types of fuel cells available, direct methanol fuel cells (DMFCs) are promising power sources for various applications, such as vehicles, cell phones, and laptops, because of their relatively low operating temperature and high power density [1-4]. However, a lack of highly efficient and inexpensive anodic catalysts remains an encumbrance to commercial application of DMFCs. We show herein that tungsten carbide (WC) sandwiched in reduced graphene oxide
(RGO) layers improves the mass and charge transfer ability, and thus, application to catalysis.

Pt and Pt alloy supported on carbon are excellent electrocatalysts for methanol oxidation reaction (MOR) [5], but the high cost, poor utilization coefficient [4], and ease of CO poisoning of Pt seriously narrows their practical application in DMFCs. WC as a non-noble catalyst is confirmed to have "platinum-like" properties because of its similar structure with $\mathrm{Pt}$ [6]. To reduce the amount of Pt required in DMFCs, WC is considered to be a promising co-catalyst of Pt metal because of its

\footnotetext{
* Corresponding author. Tel/Fax: +86-571-88320830; E-mail: science@zjut.edu.cn

This work was supported by the International Science \& Technology Cooperation Program of China (2010DFB63680); the National Natural Science Foundation of China (21376220); and Zhejiang Provincial Natural Science Foundation of China (LY16B060009, LY12B03008).

DOI: 10.1016/S1872-2067(16)62535-4 | http://www.sciencedirect.com/science/journal/18722067 | Chin. J. Catal., Vol. 37, No. 11, November 2016
} 
strong interaction with Pt [7]. Surface science and electrochemical studies indicate that, in the presence of $\mathrm{Pt}, \mathrm{WC}$ is active in MOR and water decomposition, which is crucial for removing CO from the Pt surface [8,9]. However, the low conductivity and small surface area of WC limits its catalytic activity in MOR.

To improve the conductivity and synergistic effect between WC and Pt, a support with higher electroconductivity and greater surface area, and significant interfaces are required. RGO is selected as an ideal support for loading WC to promote the conductivity and surface area of the catalyst. In general, the formation of a graphene intercalation compound can not only inhibit the stacking of graphene to obtain few-layer structures, but also increase the interlayer spacing to improve the mass and charge transfer [10], which greatly enhances the electrocatalytic activity. The intercalated layered materials used in this work were designed and studied by our group previously [11]. However, WC particles with a diameter of $20 \mathrm{~nm}$ were inclined to load onto the edges of the RGO, which lowered the electrocatalytic activity towards MOR.

Intercalation compounds of graphene sandwiched with transition metal carbides (TMCs) are not easily obtained because the TMCs are generally prepared by a direct reduction carbonization method that inevitably leads to large sized molecules and poor dispersion of the catalysts [12]. However, in the case of $\mathrm{WC}$, direct attachment of metatungstate ions, $\left[\mathrm{H}_{2} \mathrm{~W}_{12} \mathrm{O}_{40}\right]^{6-}$, onto graphene oxide (GO) is difficult to realize because the negative charges of both $\left[\mathrm{H}_{2} \mathrm{~W}_{12} \mathrm{O}_{40}\right]^{6-}$ and $\mathrm{GO}$ are unfavorable for assembly of the particles. Thiourea is a known, remarkably simple neutral receptor for anion recognition because of its strong ability to bind anions to form stable complexes through hydrogen bonds [13-16]. Therefore, we might assume that thiourea can be used as a bridge to connect two anions. Thiourea is also used to form transition metal sulfides, which have graphene-like sheet structures that can be assembled with graphene to develop intercalation compounds [17]. Subsequently, a WC-RGO intercalation compound can be obtained by in situ reduction carbonization method from tungsten disulfide $\left(\mathrm{WS}_{2}\right)$ sandwiched in RGO layers. To the best of our knowledge, the use of thiourea as an anchoring and inducing reagent for the preparation of a carbide-graphene intercalation compound has not been reported to date.

In this work, ultra-small-sized tungsten carbide sandwiched in RGO layers, forming a WC-RGO intercalation compound (WC-RGO), was prepared by a facile and efficient method by adding thiourea as an anchoring and inducing reagent. We propose that the excellent performance of Pt/WC-RGO is related to the ultra small size and high dispersion of WC on the few-layer RGO. The intercalated structure, which increases the probability of WC coming into contact with Pt, promotes synergistic effects and improves the mass and charge transfer ability.

\section{Experimental}

\subsection{Preparation of Pt/WC-RGO}

GO was prepared from flake graphite using a modified
Hummers method [18]. Specific steps are as follows. Flake graphite (3.0 g), $\mathrm{KMnO}_{4}(18.0 \mathrm{~g})$, and concentrated phosphoric acid $(40 \mathrm{~mL})$ were put into a $1000-\mathrm{mL}$ flask under magnetic stirring in an ice bath for $2 \mathrm{~h}$ while concentrated $\mathrm{H}_{2} \mathrm{SO}_{4}(360$ $\mathrm{mL}$ ) was added to the mixture slowly. Then, the mixture was stirred in a water bath at $50{ }^{\circ} \mathrm{C}$ for $12 \mathrm{~h}$ followed by dropwise addition of $10 \mathrm{~mL} \mathrm{H}_{2} \mathrm{O}_{2}$. Finally, the mixture was centrifuged and washed with $\mathrm{HCl}$ aqueous solution and deionized water several times. The resulting solid was dispersed in $600 \mathrm{~mL}$ deionized water and sonicated for $2 \mathrm{~h}$ to form GO aqueous dispersion. GO was derived by freeze-drying the GO aqueous dispersion. For preparation of Pt/WC-RGO, ammonium metatungstate (AMT) was added after thiourea and the GO dispersion was stirred for some time. Then, the mixture was stirred for another $12 \mathrm{~h}$ and freeze-dried to obtain the precursor that was then put into a ceramic boat and placed into a tubal furnace. The furnace temperature was preserved at $700{ }^{\circ} \mathrm{C}$ for $1 \mathrm{~h}$ in $\operatorname{Ar}(100 \mathrm{~mL} / \mathrm{min})$ and $900{ }^{\circ} \mathrm{C}$ for $3 \mathrm{~h}$ in $\mathrm{CO}(100 \mathrm{~mL} / \mathrm{min})$ and $\mathrm{H}_{2}(20 \mathrm{~mL} / \mathrm{min})$. The obtained black powder was denoted as WC-RGO. $10 \mathrm{wt} \%$ Pt/WC-RGO was obtained by the method published in our previous work [11]. Pt/C catalyst (20\% Pt on Vulcan XC-72R, Johnson Matthey Corp.) was used as a comparative sample.

\subsection{Physical characterization}

The crystallite structures were investigated by X-ray diffraction (XRD) with an X'Pert PRO X-ray system (PANalytical, Netherlands) at room temperature. $\mathrm{Cu} K_{\alpha}$ radiation $(40 \mathrm{kV}, 40$ $\mathrm{mA}$ ) was applied and an angle range from $10^{\circ}$ to $80^{\circ}$ was recorded at 0.05 increments. The morphologies of the samples were observed by scanning electron microscope (SEM) (Hitachi S-4700II, Hitachi, Japan) using $\mathrm{Cu} K_{\alpha}$ radiation $(\lambda=0.154 \mathrm{~nm})$. Transmission electron microscopy (TEM) and scanning transmission electron microscopy (STEM) were performed with a Tecnai G2 F30S-Twin microscope (FEI, Netherlands), coupled with energy dispersive X-ray spectrometry (EDX, Thermo NORAN VANSTAGE ESI), using $\mathrm{Cu} K_{\alpha}$ radiation. The element distribution of the catalyst was characterized by EDX. Raman spectroscopy was performed using a Lab RAM HR UV800 Raman microscope (JOBIN YVON, France) with a laser emission wavelength of $632.81 \mathrm{~nm}$ from a frequency range of 2000 to $600 \mathrm{~cm}^{-1}$.

\subsection{Electrochemical measurements}

Electrochemical properties were measured on a CHI660D (Chen-hua, Shanghai, China) using a three-electrode electrochemical cell. Platinum electrodes and saturated calomel electrodes (SCEs) were used as the counter and reference electrodes, respectively. The working electrode was prepared as in our previous work [11]. The cyclic voltammetry (CV) and chronoamperometry (CA) was tested in $0.5 \mathrm{~mol} / \mathrm{L} \mathrm{H}_{2} \mathrm{SO}_{4}+0.5$ $\mathrm{mol} / \mathrm{L} \mathrm{CH}_{3} \mathrm{OH}$, at a scan rate of $50 \mathrm{mV} / \mathrm{s}$ at $50{ }^{\circ} \mathrm{C}$. For CO stripping measurements, $0.5 \mathrm{~mol} / \mathrm{L}_{2} \mathrm{SO}_{4}$ solution was bubbled with $\mathrm{N}_{2}$ for $0.5 \mathrm{~h}$, then the CO absorption was performed at a constant potential of $-0.14 \mathrm{~V}$ vs. SCE. The excess CO in the elec- 
trolyte was removed by bubbling $\mathrm{N}_{2}$ vigorously. Finally, the stripping voltammograms were recorded from -0.1 to $1 \mathrm{~V}$ at a scan rate of $20 \mathrm{mV} / \mathrm{s}$ at room temperature. Accelerated durability testing (ADT) was carried out by cycling the electrode potential, under nitrogen saturation, for 100 cycles between 0.6 and $1.0 \mathrm{~V}$ (vs. SCE) in $0.5 \mathrm{~mol} / \mathrm{L} \mathrm{H}_{2} \mathrm{SO}_{4}$ at a scan rate of $50 \mathrm{mV} / \mathrm{s}$ at $50{ }^{\circ} \mathrm{C}$

\section{Results and discussion}

\subsection{Physical characterization of WC-RGO and Pt/WC-RGO}

Fig. 1(a) shows the XRD patterns of WC-RGO and Pt/WC-RGO. It can be seen that both samples have strong $\mathrm{C}$ (002) diffraction peaks at $25.6^{\circ}$, characteristic of parallel RGO sheets. The peaks are $0.8^{\circ}$ less than that of graphite $\left(26.4^{\circ}\right)$ [11], which may be the result of the introduction of $\mathrm{WS}_{2}$ to form $\mathrm{WS}_{2}$-RGO intercalation compound, and final product WC that prevents the aggregation of RGO while increasing the interlayer spacing. In the XRD patterns of Pt/WC-RGO, the distinct diffraction peaks located at $39.7^{\circ}, 46.1^{\circ}$, and $67.5^{\circ}$ are indexed to (111), (200), and (220) planes, respectively, of Pt (JCPDS 01-089-7382). For WC-RGO, the peaks located at $31.3^{\circ}, 35.5^{\circ}$, $48.0^{\circ}, 64.1^{\circ}, 73.0^{\circ}$, and $75.9^{\circ}$ can be identified as the $(001)$, (100), (101), (110), (111), and (102) reflections, respectively, of hexagonal WC phase (JCPDS 00-025-1047). However, the peaks belonging to $\mathrm{WC}$ weaken for Pt/WC-RGO, which may suggest that WC is too small in size and is uniformly dispersed on the RGO layers. Similar results are also observed for Pt-WC/carbon and Pt-Mo2 C/carbon [19,20]. The observation can be explained by the strong interaction of Pt with WC NPs and epitaxial growth of Pt on WC that results from the similar electronic structures of these species [21]. No other diffraction peaks are detected, implying a high purity of the WC phase.

Raman spectroscopy was used to study the evolution of the crystal structure and the nature of the chemical bonds in the samples during assembly from graphite and GO to WC-RGO. Fig. 1(b) shows the Raman results of graphite, GO, and

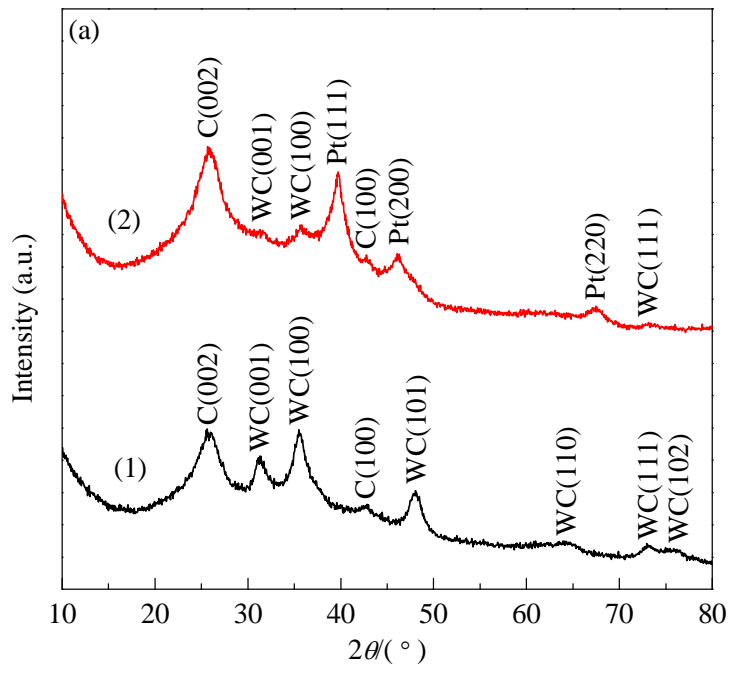

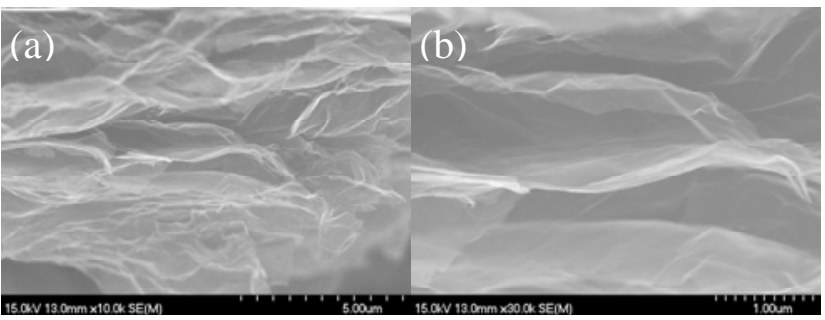

Fig. 2. Low- (a) and high-magnification (b) SEM images of WC-RGO.

WC-RGO. All three samples have a characteristic D band and G band at about 1333.2 and $1578.2 \mathrm{~cm}^{-1}$, respectively. However, the G band of WC-RGO intercalation compound is shifted marginally to a higher wavenumber, which is probably caused by the WC that is sandwiched in the RGO layers forming an intercalated structure. An increased $\mathrm{D} / \mathrm{G}$ intensity ratio $\left(\mathrm{I}_{\mathrm{D}} / I_{\mathrm{G}}\right)$ of graphite and GO relative to WC-RGO is also observed. $I_{\mathrm{D}} / I_{\mathrm{G}}$ is used to quantify defects and disorder in graphene-related systems, which include a large family of $s p^{2}$ carbon structures [22]. Samples with a higher $I_{\mathrm{D}} / I_{\mathrm{G}}$ value tend to have more defects and disorder in their structure. Compared with graphite, GO has a higher $I_{\mathrm{D}} / I_{\mathrm{G}}$ value as a result of the oxygen-containing group introduced by the oxidation reaction. For WC-RGO, the increased $I_{\mathrm{D}} / I_{\mathrm{G}}$ value confirms the success of loading $\mathrm{WC}$ between the layers of RGO.

From the SEM image shown in Fig. 2(a), thin and transparent RGO layers can be clearly observed at low magnification, suggesting few layers are evident. The RGO sheets also have the characteristic shape of a crumpled silk veil, which is reported to be part of the intrinsic nature of graphene sheets [23]. From the high magnification SEM image of WC-RGO (Fig. 2(b)), crumpled RGO sheets with an extraordinarily large interlayer spacing are presented, which is consistent with the XRD results. The formation of few-layer RGO sheets with a large interlayer spacing should be related to growth of $\mathrm{WS}_{2}$ developing an intercalation compound with RGO, which acts as a space for separating RGO and prevents stacking like a sandwich. However, the WC parti-

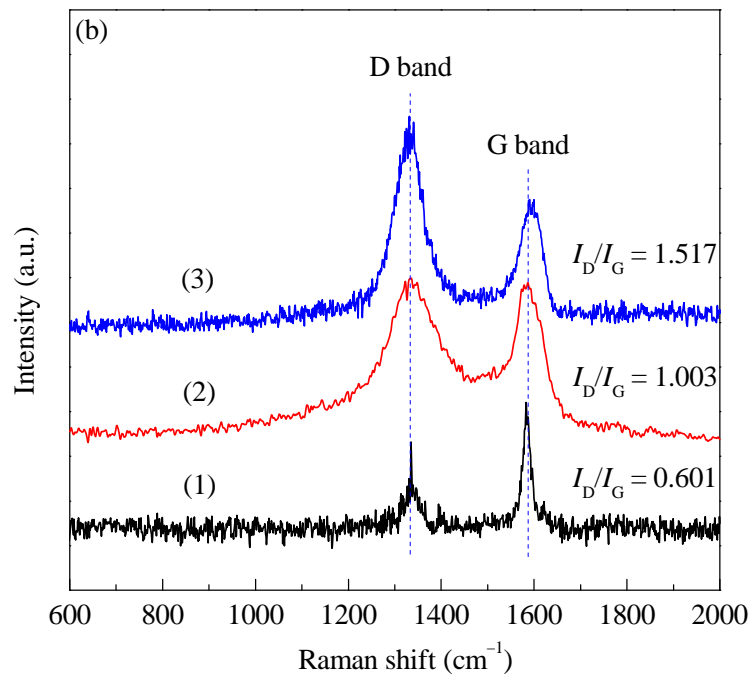

Fig. 1. (a) XRD patterns of WC-RGO (1) and Pt/WC-RGO (2); (b) Raman spectra of graphite (1), GO (2), and WC-RGO (3). 
cles cannot be found on the RGO sheets from SEM directly, probably because of the small size and good dispersion that are beyond the resolution limit of our SEM instrument.

TEM and high-resolution TEM (HRTEM) images of WC-RGO and Pt/WC-RGO are provided to give more detailed information. From Fig. 3(a), WC NPs of uniform size and with homogeneous distribution on the RGO sheet can be clearly observed. The inset image of Fig. 3(a) shows the size distribution of WC NPs, which confirms that WC is homogeneously dispersed on the support without agglomeration, with a mean particle diameter of $1.5 \mathrm{~nm}$ (one of the smallest WC sizes reported in the literature) [24-29]. The smaller size and better dispersion of WC on the RGO sheets significantly increases the probability of contact with Pt NPs, which can eventually enhance the synergistic effects between Pt and WC for MOR. The HRTEM image in Fig. 3(b) shows that the distances of two adjacent planes of a single WC and Pt particle are about 0.188 and $0.229 \mathrm{~nm}$, corresponding to the (101) and (111) crystal faces of the hexagonal $\mathrm{WC}$ and $\mathrm{Pt}$, respectively. The intimate contact between Pt and WC is also confirmed, and this can improve the electro-oxidation activity towards MOR by promoting the synergistic effects. From the inset image of Fig. 3(b), the carbon sheets that are about 5 layers thick confirm the successful synthesis of few-layer RGO. The distribution of the Pt, WC, and RGO phase is displayed by EDX and the corresponding result is shown in Fig. 3(c). The top right corner is the mapped images of the elements $\mathrm{Pt}, \mathrm{W}$, and $\mathrm{C}$, respectively. The characterization of $\mathrm{W}$ and $\mathrm{C}$ shows that most of the selected area is filled with WC and RGO. The reason for this may be that WC NPs are small enough and sufficiently dispersed that they cover the RGO sheet uniformly. The characterization of $\mathrm{Pt}$ indicates that $\mathrm{Pt}$ particles also disperse well on the support. The small-sized and highly dispersed WC is consistent with the results from SEM.

\section{2. $C V, C O$ stripping, chronoamperometric and $A D T$}

The electrochemical surface area (ECSA) not only determines the number of catalytically active sites available for an electrochemical reaction, but is also a significant parameter to compare different electrocatalytic supports by accounting for the conductive path available for electron transfer [30]. The CV of Pt/WC-RGO and commercial Pt/C tested at a scan rate of 50 $\mathrm{mV} / \mathrm{s}$ in $0.5 \mathrm{~mol} / \mathrm{L} \mathrm{H}_{2} \mathrm{SO}_{4}$ solution at $50{ }^{\circ} \mathrm{C}$ is shown in Fig. 4(a). In the range between -0.2 and $0.1 \mathrm{~V}$ (vs. SCE), typical hydrogen adsorption and desorption peaks are observed, from which the ECSA of the as-prepared samples can be estimated by employing the equation [30]:

$$
\text { ECSA }\left(\mathrm{cm}^{2} / \mathrm{g} \text { of } \mathrm{Pt}\right)=\frac{\text { Charge }\left(Q_{\mathrm{H}}, \mu \mathrm{C} / \mathrm{cm}^{2}\right)}{210\left(Q_{\mathrm{H}}, \mu \mathrm{C} / \mathrm{cm}^{2}\right) \times \text { electrode loading }\left(\mathrm{g} \text { of } \mathrm{Pt} / \mathrm{cm}^{2}\right)}
$$

The result indicates that the ECSA value of Pt/WC-RGO is promoted and is 3.66 times greater than that of commercial $\mathrm{Pt} / \mathrm{C}$ (Table 1), suggesting better performance for MOR. This extraordinary performance can be explained as the result of the intimate contact between $\mathrm{Pt}$ and $\mathrm{WC}$, anchoring on the few-layer RGO support with the intercalated structure.

The $\mathrm{CV}$, after stabilization, of methanol electro-oxidation on $\mathrm{Pt} / \mathrm{WC}-\mathrm{RGO}$ and commercial Pt/C tested at a scan rate of 50 $\mathrm{mV} / \mathrm{s}$ in $0.5 \mathrm{~mol} / \mathrm{L} \mathrm{H}_{2} \mathrm{SO}_{4}+0.5 \mathrm{~mol} / \mathrm{L} \mathrm{CH}_{3} \mathrm{OH}$ solution at $50{ }^{\circ} \mathrm{C}$
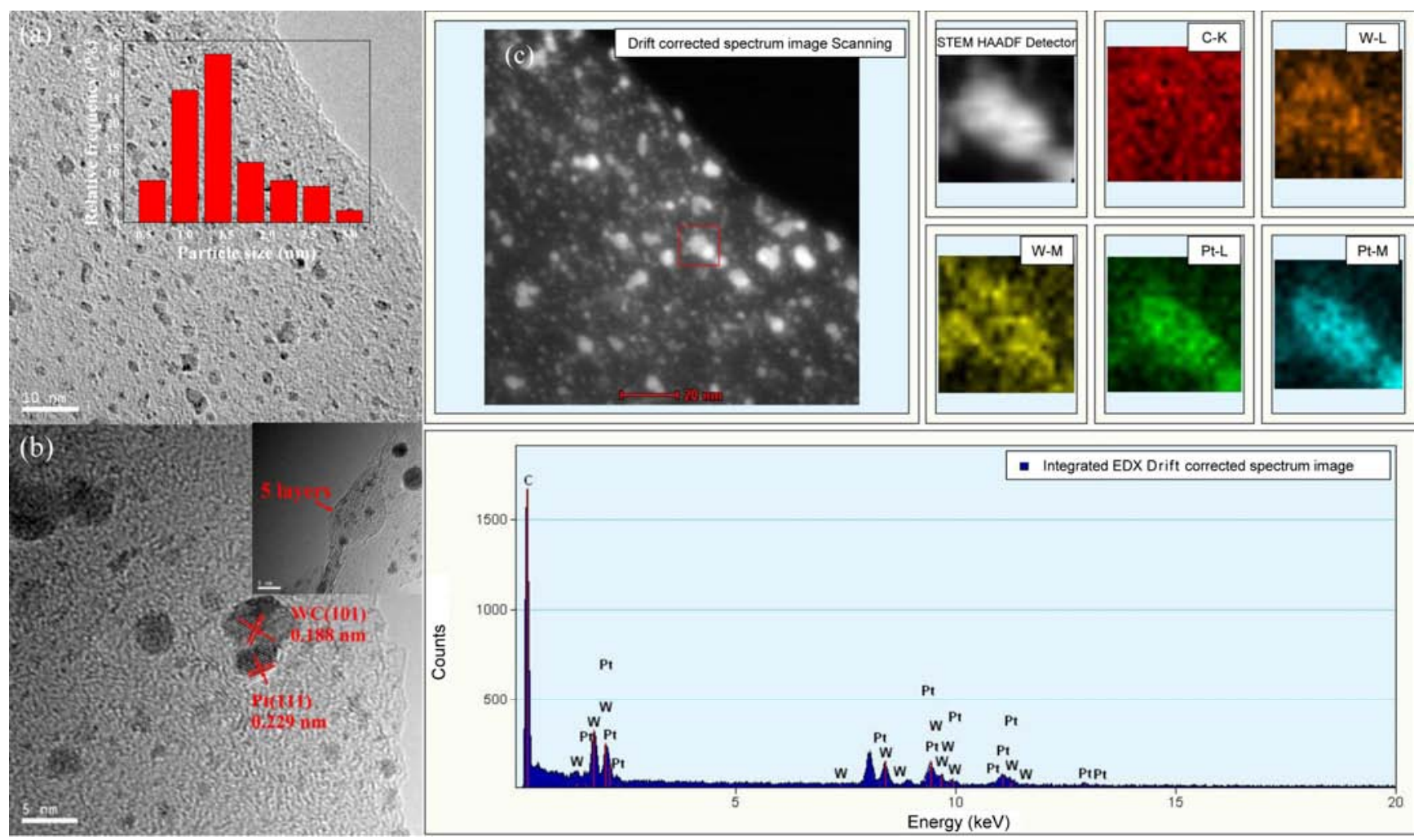

Fig. 3. (a) TEM image of WC-RGO and the particle size distribution of WC NPs (inset). (b) HRTEM image of Pt/WC-RGO and the margin of RGO layers (inset). (c) Mapped images from the corresponding EDX analysis of Pt/WC-RGO. 

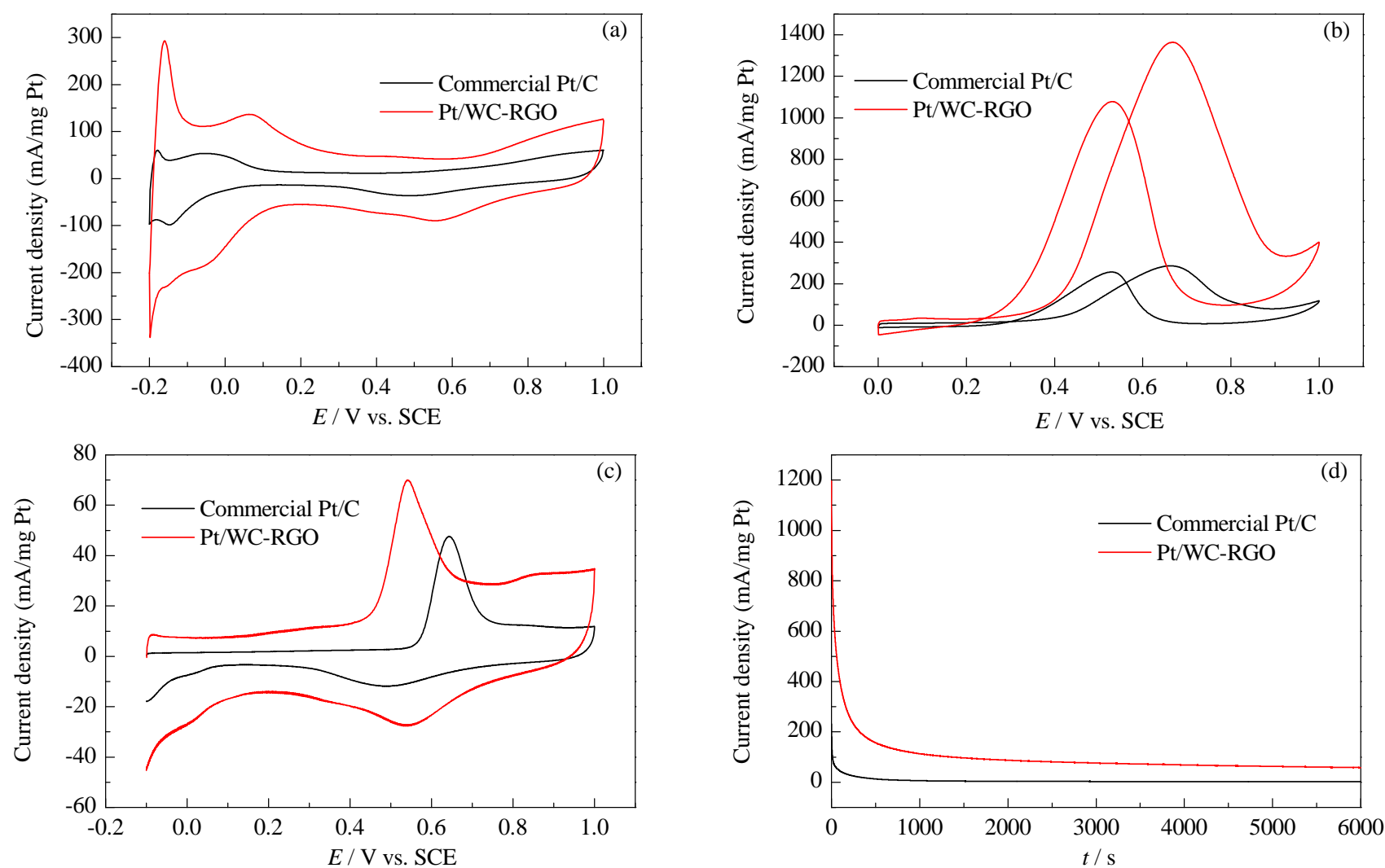

Fig. 4. $\mathrm{CV}$ curves of $\mathrm{Pt} / \mathrm{WC}-\mathrm{RGO}$ and $\mathrm{Pt} / \mathrm{C}$ tested at a scan rate of $50 \mathrm{mV} / \mathrm{s}$ in $0.5 \mathrm{~mol} / \mathrm{L} \mathrm{H}_{2} \mathrm{SO}_{4}$ solution (a), $0.5 \mathrm{~mol} / \mathrm{L} \mathrm{H}_{2} \mathrm{SO}_{4}+0.5 \mathrm{~mol} / \mathrm{L} \mathrm{CH} \mathrm{OH}_{3} \mathrm{solu}-$ tion (b). (c) CO stripping experiments of Pt/WC-RGO and Pt/C tested at a scan rate of $20 \mathrm{mV} / \mathrm{s}$ in $0.5 \mathrm{~mol} / \mathrm{L} \mathrm{H}_{2} \mathrm{SO}_{4}$ solution. (d) chronoamperometry curves of Pt/WC-RGO and Pt/C tested at a scan rate of $50 \mathrm{mV} / \mathrm{s}$ in $0.5 \mathrm{~mol} / \mathrm{L} \mathrm{H}_{2} \mathrm{SO}_{4}+0.5 \mathrm{~mol} / \mathrm{L} \mathrm{CH}_{3} \mathrm{OH}$ solution at room temperature.

is presented in Fig. 4(b). The two CV curves show similar methanol oxidation current peaks in the positive and negative potentials. However, both the forward anodic peak current ( $\left.I_{\mathrm{f}}\right)$ and the backward anodic peak current $\left(I_{b}\right)$ on Pt/WC-RGO are much higher than those on commercial $\mathrm{Pt} / \mathrm{C}$ and other electrocatalysts reported in the literature (Table 1). The typical forward and backward anodic peak at around 0.7 and $0.4 \mathrm{~V}$ is attributed to the electrooxidation of methanol and a Faradaic oxidation reaction on the catalysts by residual intermediate species such as $\mathrm{CH}_{2} \mathrm{OH}, \mathrm{CH}_{2} \mathrm{O}, \mathrm{HCOOH}$, and $\mathrm{CO}$ [32]. The value of $I_{\mathrm{f}} / I_{\mathrm{b}}$ can be used to infer the tolerance of a catalyst to the intermediate carbonaceous species formed via decomposition of methanol and accumulated on the electrode surface [33]. Therefore, a higher value of $I_{\mathrm{f}} / I_{\mathrm{b}}$ is indicative of, e.g., enhanced CO-tolerance. It is notable that the Pt/WC-RGO catalyst gives a much higher value of $I_{\mathrm{f}} / \mathrm{I}_{\mathrm{b}}$, which means that the Pt-WC/RGO may be much more tolerant to the intermediate carbon species and, consequently, can much more efficiently facilitate the oxidization of methanol to carbon dioxide. Additionally, the onset potential $\left(E_{0}\right)$ for MOR on Pt/WC-RGO starts at $0.242 \mathrm{~V}$, which is $57 \mathrm{mV}$ more negative compared with that on commercial $\mathrm{Pt} / \mathrm{C}$. These results indicate that the methanol can be easily oxidized and the oxidative removal of the intermediates generated from MOR can also occur more easily on Pt/WC-RGO compared with commercial Pt/C. The higher catalytic activity demonstrated by Pt/WC-RGO can be attributed to the increased interfaces provided by the intercalated structure of WC-RGO, where CO can be easily removed from Pt sites as a result of the synergistic effect between WC and Pt [34,35].

The excellent CO tolerance of Pt/WC-RGO is further demon-

Table 1

Comparison of the electrochemical performance observed for the electrocatalysts in MOR.

\begin{tabular}{lcccccccc}
\hline Catalyst & $\begin{array}{c}\text { ECSA } \\
\left(\mathrm{m}^{2} / \mathrm{g} \mathrm{Pt}\right)\end{array}$ & $E_{\mathrm{o}} / \mathrm{V}$ & $E_{\mathrm{f}} / \mathrm{V}$ & $E_{\mathrm{b}} / \mathrm{V}$ & $\begin{array}{c}I_{\mathrm{f}} \\
(\mathrm{mA} / \mathrm{mg} \mathrm{Pt})\end{array}$ & $\begin{array}{c}I_{\mathrm{b}} \\
(\mathrm{mA} / \mathrm{mg} \mathrm{Pt})\end{array}$ & $I_{\mathrm{f}} / \mathrm{I}_{\mathrm{b}}$ & Ref. \\
\hline Pt/WC-RGO & 246.1 & 0.242 & 0.668 & 0.529 & 1364.7 & 1078.8 & 1.265 & This work \\
Pt/C & 67.2 & 0.299 & 0.663 & 0.529 & 286.0 & 256.4 & 1.115 & This work \\
Pt-WC/graphene & 103.8 & $\approx 2$ & 0.70 & - & 686.6 & - & - & {$[10]$} \\
Pt/WC/GC & 57.0 & $\approx 2$ & 0.65 & - & 416.1 & - & 1.11 & {$[31]$} \\
\hline
\end{tabular}

$E_{\mathrm{f}}, E_{\mathrm{b}}$, and $E_{\mathrm{o}}$ represent the forward, backward, and onset potential (V vs. SCE), respectively. $I_{\mathrm{f}}$ and $I_{\mathrm{b}}$ represent the forward and backward anodic peak current density respectively.

$\mathrm{GC}=$ graphitic carbon.

The active Pt metal surface area was estimated by assuming a monolayer of adsorbed $\mathrm{H}$ and a Coulombic charge of $210 \mu \mathrm{C} / \mathrm{cm}^{2}$ for oxidation. 
strated by CO stripping tests at a scan rate of $20 \mathrm{mV} / \mathrm{s}$ in 0.5 mol/ $\mathrm{L} \mathrm{H}_{2} \mathrm{SO}_{4}$ solution at room temperature (Fig. 4(c)). The oxidation of $\mathrm{CO}$ requires $\mathrm{H}_{2} \mathrm{O}$ dissociation or activation [36]. The WC nanocrystallites are active in water decomposition and can provide the $\mathrm{OH}_{a d}$ species to oxidize the adsorbed CO on Pt surfaces. Furthermore, the enhanced contact between Pt and WC profiting from the intercalated nanostructure could favor a decrease in the mass and charge transfer limits, which, consequently, brings the synergistic effect into play [10]. The Pt/WC-RGO has a peak potential of $0.540 \mathrm{~V}$, which is $104 \mathrm{mV}$ more negative than that of commercial $\mathrm{Pt} / \mathrm{C}$. This means that $\mathrm{CO}$ can be more easily oxidized at a lower potential on the surface of Pt/WC-RGO compared with commercial Pt/C. The easier removal of $\mathrm{CO}$ on the Pt/WC-RGO directly leads to a refreshment of Pt sites that subsequently results in the slow degradation of the catalyst. It is notable that the removal of intermediate species benefited from the intercalated structure with well dispersed WC and Pt on it because this layer-by-layer construction is a functional system to assemble the support RGO, promoter WC, and active component Pt without aggregation. This result is in agreement with the good mass and charge transfer ability and excellent CO poisoning-tolerance of WC-RGO intercalation compound.

The catalytic stability of a catalyst is a key factor in determining its applicability on a commercial scale. To estimate the stability of the catalyst, chronoamperometry (CA) was performed in $0.5 \mathrm{~mol} / \mathrm{L} \mathrm{H}_{2} \mathrm{SO}_{4}+0.5 \mathrm{~mol} / \mathrm{L} \mathrm{CH}_{3} \mathrm{OH}$ solution (Fig. $4(d)$ ). As is shown, the performances of both catalysts show that the polarization current initially decreases rapidly because of the formation of intermediates during the methanol oxidation; however, Pt/WC-RGO decreases relatively slowly. After $6000 \mathrm{~s}$, the current value of Pt/WC-RGO is much higher than that of commercial Pt/C, which indicates that the Pt/WC-RGO catalyst has much better long-term stability compared with commercial Pt/C. The enhanced stability may be attributed to the improved synergistic effect between Pt and WC from the intercalated structure that prevents the small Pt particles from being poisoned by CO. WC-RGO intercalation compound provides not only intimate contact between $\mathrm{Pt}$ and $\mathrm{WC}$ to make full use of the synergistic effect, but also few-layer RGO to increase the mass and charge transfer ability. Thus, a smaller amount of $\mathrm{Pt}$ is needed to generate a higher current and a substantial amount of noble metal can be saved.

To further investigate catalyst durability, accelerated durability testing (ADT) is commonly employed to simulate the harsh, potentiodynamic, and corrosive conditions encountered at the cathode of proton exchange membrane fuel cells (PEMFCs) during operation [37]. For the three-electrode system, 0.6 and $1.0 \mathrm{~V}$ (vs. SCE) were chosen as the potential for the degradation of the catalysts (Fig. 4(c)). The Pt/WC-RGO and commercial Pt/C catalysts were subjected to 100 cycles using multi-potential steps between 0.6 and $1.0 \mathrm{~V}$ in nitrogen-saturated $0.5 \mathrm{~mol} / \mathrm{L} \mathrm{H}_{2} \mathrm{SO}_{4}$ with CVs collected after every 10 cycles of ADT. The stabilities of commercial Pt/C and Pt/WC-RGO were compared after 100 cycles of ADT, as shown in Fig. 5(a) and 5(b), respectively. Compared with commercial Pt/C,
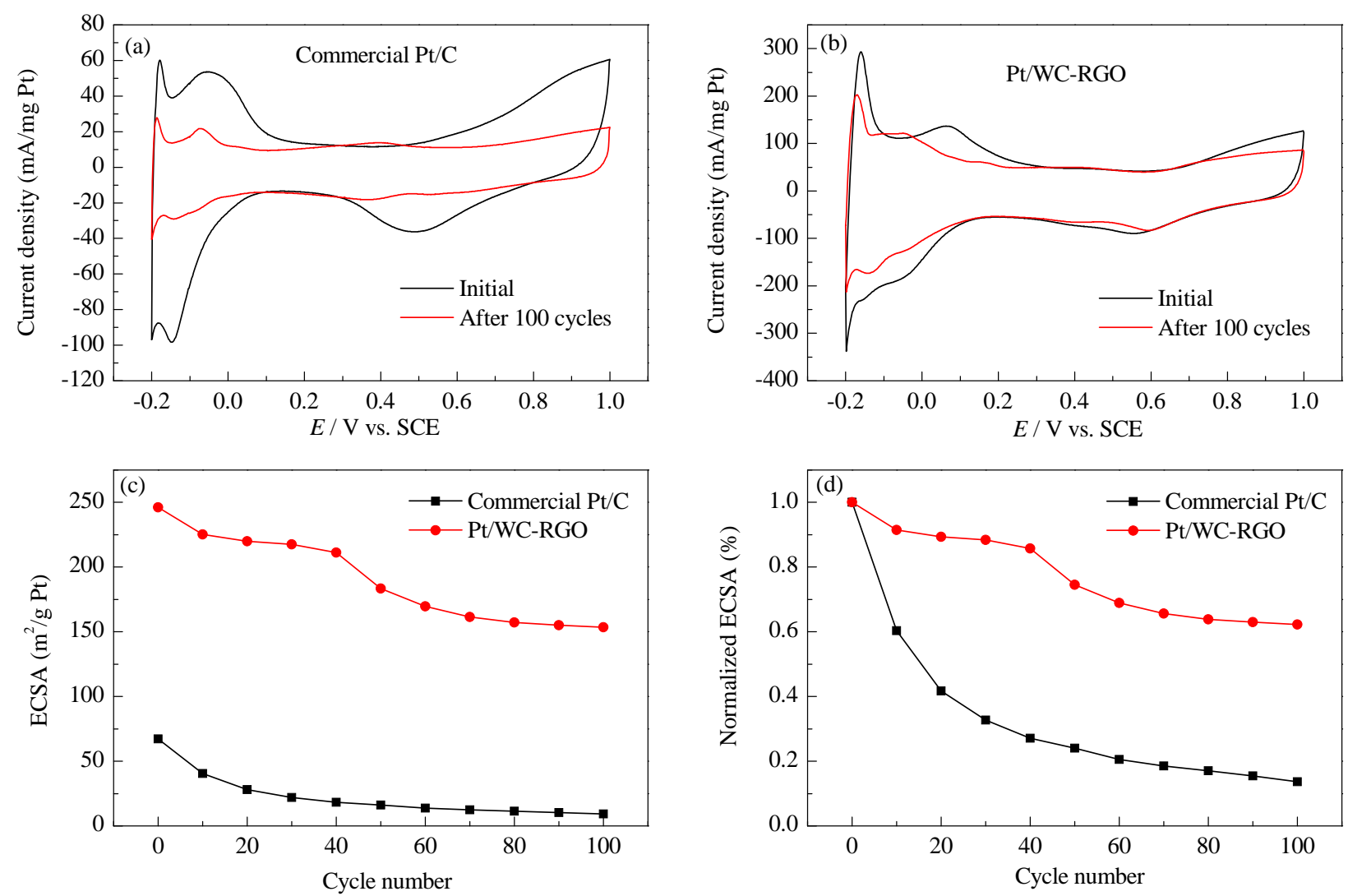

Fig. 5. Initial CV curves and those after accelerated durability testing (ADT) of 100 cycles for commercial Pt/C (a), Pt/WC-RGO (b), ECSA (c), and normalized ECSA remaining throughout ADT (d). 
Pt/WC-RGO clearly provides a higher double layer current density, attributed to the special intercalated structure of our catalyst. Furthermore, the platinum oxide reduction peak for commercial Pt/C almost disappears after 100 cycles, which implies an increase in particle size as a result of aging [38] and surface restructuring of $\mathrm{Pt}$ particles, resulting in a passivated surface and a reduction in the number of highly exposed $\mathrm{Pt}$ atoms [29]. However, the platinum oxide reduction peak for Pt/WC-RGO remains relatively unchanged, which indicates that the Pt/WC-RGO maintains its original structure upon reaction. ECSA values were confirmed based on the calculated charge for hydrogen adsorption-desorption initially and after each 10 subsequent cycles. As is shown in Fig. 5(c), the ECSA value of Pt/WC-RGO catalyst decreased relatively fast for the first 10 cycles and then degraded slowly until the 50th cycle before maintaining a value of $153.5 \mathrm{~m}^{2} / \mathrm{g}$ Pt after 100 cycles. However, in the case of commercial Pt/C, the ECSA value decreased rapidly throughout the ADT process and dropped to $9.2 \mathrm{~m}^{2} / \mathrm{g} \mathrm{Pt}$ after 100 cycles. This result indicates that the Pt/WC-RGO catalyst, to some extent, has the ability to resist the degradation caused by the harsh conditions. From Fig. 5(d), it can be clearly seen that the ECSA retention for Pt/WC-RGO is superior to that for commercial $\mathrm{Pt} / \mathrm{C}$, retaining $62.3 \%$ and $13.7 \%$ of their initial ECSA after 100 cycles, respectively. The excellent long-term stability of the former is primarily attributed to the intercalated structure that not only prevents the intrinsic structure from being poisoned, but also enhances the mass and charge transfer ability for MOR. From the electrochemistry measurements it is observed that Pt/WC-RGO catalyst demonstrates a higher electrochemical activity, which is related to the special intercalated structure of Pt/WC-RGO. In the well-organized catalysts studied, WC NPs are highly dispersed on the thiourea-modified graphene oxide, and are assembled to obtain the WC-RGO intercalated structure using thiourea as an anchoring reagent. Compared with simple methods, the means of assembly through use of an anchoring reagent in this work is inclined to acquire an intercalated structure with a larger ECSA value and intimate contact of WC and Pt. The intercalated structure facilitates the dispersal and anchoring of both Pt and WC, which is beneficial for the synergistic effect between Pt and WC. The promoted synergistic effect accelerates the removal of $\mathrm{CO}$ on the surface of $\mathrm{Pt}$ and decomposition of the intermediate carbonaceous species formed during the process of methanol electro-oxidation. As a result, the catalyst we have prepared has improved tolerance of $\mathrm{CO}$ and long-term stability during the catalytic process.

\section{Conclusions}

WC-RGO intercalation compound has been constructed by anchoring WC NPs (about $1.5 \mathrm{~nm}$ in diameter) on few-layer RGO sheets based on a controllable assembly. The use of thiourea as the anchoring and inducing reagent to bridge the $\left[\mathrm{H}_{2} \mathrm{~W}_{12} \mathrm{O}_{40}\right]^{6-}$ and GO has not been reported before. The intercalation compound has a characteristic structure with ultra-small-sized WC NPs sandwiched in few-layer RGO sheets. This improves the conductivity for fast mass and charge trans- fer. That gives the intercalation compound great potential as a support of Pt for electrocatalytic application. This structure also provides intimate contact between WC and Pt after loading low amounts of $\mathrm{Pt}$. Compared with commercial $\mathrm{Pt} / \mathrm{C}$, the Pt/WC-RGO catalyst possesses higher electrochemical activity. Possible applications may include many areas, such as hydrogenation, dehydrogenation, and hydrogenolysis as WC-RGO intercalation compound has more active sites and a larger specific surface area than does commercial Pt/C. The WC-RGO and other TMC intercalation compounds can be continually exploited and beneficial outcomes may be achieved for other chemical purposes.

\section{References}

[1] G. A. Olah, Angew. Chem. Int. Ed., 2005, 44, 2636-2639.

[2] M. Winter, R. J. Brodd, Chem. Rev., 2004, 104, 4245-4270.

[3] A. K. Shukla, R. K. Raman, K. Scott, Fuel Cells, 2005, 5, 436-447.

[4] J. D. Qiu, G. C. Wang, R. P. Liang, X. H. Xia, H. W. Yu, J. Phys. Chem. C, 2011, 115, 15639-15645.

[5] D. X. Cao, S. H. Bergens, J. Power Sources, 2004, 134, 170-180.

[6] R. B. Levy, M. Boudart, science, 1973, 181, 547-549.

[7] H. Chhina, S. Campbell, O. Kesler, J. Power Sources, 2008, 179, 50-59.

[8] H. H. Hwu, J. G. Chen, Chem. Rev., 2005, 105, 185-212.

[9] A. L. Stottlemyer, E. C. Weigert, J. G. Chen, Ind. Eng. Chem. Res., 2010, 50, 16-22.

[10] R. H. Wang, Y. Xie, K. Y. Shi, J. Q. Wang, C. G. Tian, P. K. Shen, H. G. Fu, Chem.-Eur. J., 2012, 18, 7443-7451.

[11] C. A. Ma, W. M. Liu, M. Q. Shi, X. L. Lang, Y. Q. Chu, Z. Y. Chen, D. Zhao, W. F. Lin, C. Hardacre, Electrochim. Acta, 2013, 114, 133-141.

[12] S. T. Oyama, Catal. Today, 1992, 15, 179-200.

[13] K. H. Lee, J. I. Hong, Tetrahedron Lett., 2000, 41, 6083-6087.

[14] P. Bühlmann, S. Nishizawa, K. P. Xiao, Y. Umezawa, Tetrahedron, 1997, 53, 1647-1654.

[15] D. A. Jose, A. Singh, A. Das, B. Ganguly, Tetrahedron Lett., 2007, 48, 3695-3698.

[16] S. Nishizawa, P. Bühlmann, M. Iwao, Y. Umezawa, Tetrahedron Lett., 1995, 36, 6483-6486.

[17] D. W. Su, S. X. Dou, G. X. Wang, Chem. Commun., 2014, 50, 4192-4195.

[18] D. C. Marcano, D. V. Kosynkin, J. M. Berlin, A. Sinitskii, Z. Z. Sun, A. Slesarev, L. B. Alemany, W. Lu, J. M. Tour, ACS Nano, 2010, 4, 4806-4814.

[19] C. Y. He, H. Meng, X. Y. Yao, P. K. Shen, Int. J. Hydrogen Energy, 2012, 37, 8154-8160.

[20] R. H. Wang, J. Yang, K. Y. Shi, B. Wang, L. Wang, G. H. Tian, B. H. Bateer, C. G. Tian , P. H. Shen, H. G. Fu, RSC $A d v ., 2013,3$, 4771-4777.

[21] J. G. Chen, Chem. Rev., 1996, 96, 1477-1498.

[22] A. C. Ferrari, D. M. Basko, Nat. Nanotechnol., 2013, 8, 235-246.

[23] J. C. Meyer, A. K. Geim, M. I. Katsnelson, K. S. Novoselov, T. J. Booth, S. Roth, Nature, 2007, 446, 60-63.

[24] M. Q. Shi, W. T. Zhang, D. Zhao, Y. Q. Chu, C. A. Ma, Electrochim. Acta, 2014, 143, 222-231.

[25] G. H. Song, M. Q. Shi, Y. Q. Chu, C. A. Ma, Electrochim. Acta, 2013, 112, 53-58.

[26] C. B. Xu, M. Q. Shi, L. Z. Kang, C. A. Ma, Mater. Lett., 2013, 91, 183-186.

[27] J. Zhang, S. H. Tang, L. Y. Liao, W. F. Yu, Chin. J. Catal., 2013, 34, 


\title{
Graphical Abstract
}

Chin. J. Catal., 2016, 37: 1851-1859 doi: 10.1016/S1872-2067(16)62535-4

\section{Tungsten carbide-reduced graphene oxide intercalation compound as co-catalyst for methanol oxidation}

Meiqin Shi, Wentian Zhang, Yingying Li, Youqun Chu, Chun'an Ma*

Zhejiang University of Technology

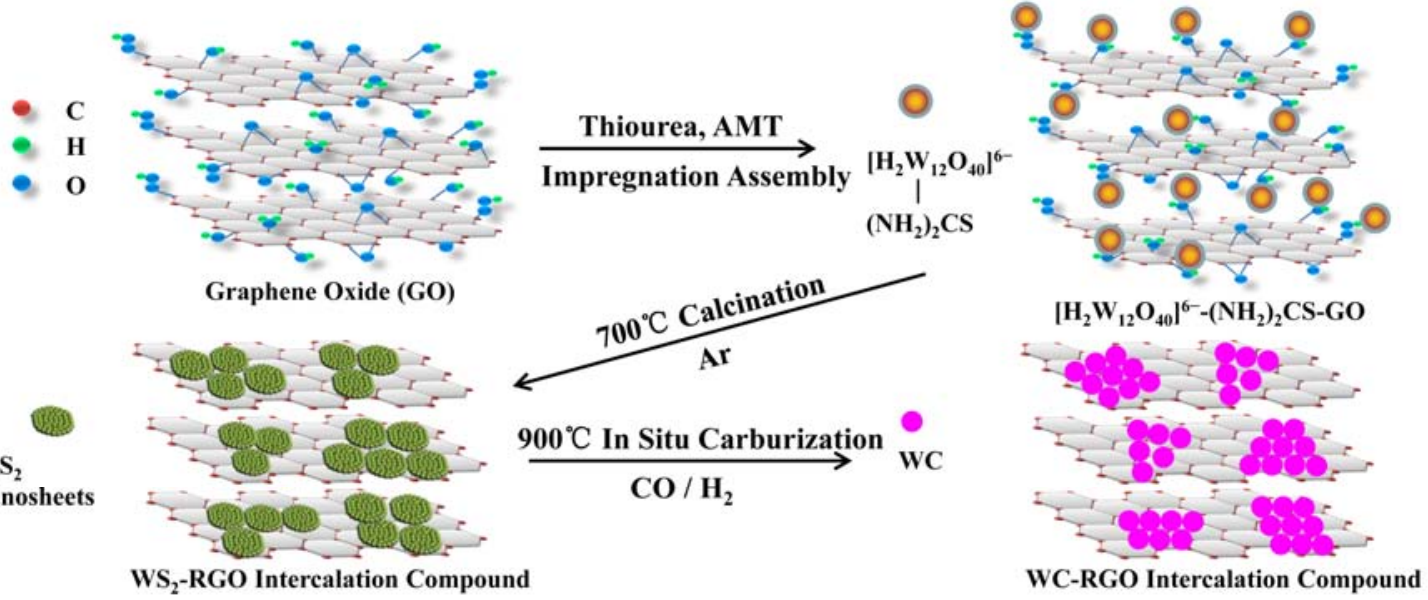

The figure represents the process of in situ reduction carburization method using thiourea as an anchoring and inducing reagent for the synthesis of WC-RGO intercalation compound.

1051-1065.

[28] Z. X. Yan, H. Meng, P. K. Shen, R. H. Wang, L. Wang, K. Y. Shi, H. G. $\mathrm{Fu}$, J. Mater. Chem., 2012, 22, 5072-5079.

[29] C. Y. He, P. K. Shen, Nano Energy, 2014, 8, 52-61.

[30] Y. J. Li, W. Gao, L. J. Ci, C. M. Wang, P. M. Ajayanb, Carbon, 2010, 48, 1124-1130.

[31] L. M. Jiang, H. G. Fu, L. Wang, G. Mu, B. J. Jiang, W. Zhou, R. H. Wang, J. Solid State Electrochem., 2014, 18, 2225-2232.

[32] X. Y. Wang, J. C. Zhang, H. Zhu, Chin. J. Catal., 2011, 32, 74-79.

[33] Y. H. Lin, C. L. Cui, C. H. Yen, C. M. Wai, Langmuir, 2005, 21, 11474-11479.
[34] M. K. Jeon, H. Daimon, K. R. Lee, A. Nakahara, S. I. Woo, Electrochem. Commun., 2007, 9, 2692-2695.

[35] Z. J. Mellinger, E. C. Weigert, A. L. Stottlemyer, J. G. Chen, Electrochem. Solid-State Lett., 2008, 11, 63-67.

[36] H. Kim, I. R. de Moraes, G. Tremiliosi-Filho, R. Haasch, A. Wieckowski, Surf. Sci., 2001, 474, L203-L212.

[37] D. Higgins, M. A. Hoque, M. H. Seo, R. Y. Wang, F. Hassan, J. Y. Choi, M. Pritzker, A. P. Yu, J. J. Zhang, Z. W. Chen, Adv. Funct. Mater., 2014, 24, 4325-4336.

[38] K. Jayasayee1, J. A. R. V. Veen, T. G. Manivasagam, S. Celebi, E. J. M. Hensen, F. A. de Bruijn, Appl. Catal. B, 2012, 111-112, 515-526.

\section{碳化铇-石墨烯插层复合物的制备及作为甲醇氧化助催化剂的性能研究}

\author{
施梅勤, 章文天, 李影影, 褚有群, 马淳安 ${ }^{*}$ \\ 浙江工业大学化学工程学院, 绿色化学合成技术国家重点实验室培育基地, 浙江杭州 310032
}

摘要: 直接甲醇燃料电池 (DMFCs) 作为一种环境友好、高效的新能源, 对解决世界目前面临的“能源危机”与“环境危机”这 两大问题有着至关重要的意义, 具有较广阔的应用前景. 目前, 甲醇氧化催化剂仍然以 Pt 基为主, 但是 Pt 价格昂贵, 且容 易受甲醇氧化中间产物的毒化, 从而影响了 DMFCs 的商业化进程. 碳化铇 (WC) 作为非贵金属催化剂, 在催化方面具有 类铂的性能. 在 WC 上负载适量的 Pt, 可以通过两者的协同效应加强催化剂的抗 CO 中毒能力. 但是, 由于 WC 的导电性 能不佳, 比表面积较小, 因此寻找合适的载体显得尤为必要. 在碳载体中, 石墨烯 (RGO) 具有优良的导电性以及独特的片 层结构, 是电催化剂的理想载体. 以 RGO 为载体, WC 为插层物质制备的 WC-RGO 插层复合物具有化学稳定性好、电导 率高且电化学活性面积大等优势. 但是, 由于石墨烯表面光滑且呈惰性, 同时使用传统的碳化方法制备的碳化钨颗粒较大, 因此, 制备较小颗粒且分散均匀的 WC-RGO 插层复合物具有较大难度. 一般以偏铇酸铵和氧化石墨烯 (GO) 为前驱体制 备 WC-RGO 插层复合物, 但是由于偏铇酸根和 GO 都带负电, 因此不能成功地将偏铇酸根引入到石墨烯的片层结构中, 造 成 WC-RGO 插层复合物组装上的困难.

本文采用硫䐂成功地合成了具有高分散性 WC 纳米颗粒插层在少层 RGO 里的 WC-RGO 插层复合物. 硫嫝 $\left(\left(\mathrm{NH}_{2}\right)_{2} \mathrm{CS}\right)$ 作为阴离子接受器, 具有较强的结合阴离子形成稳定复合物的能力, 同时它也是合成具有片层结构的过渡金属 
硫化物的原料之一. 因此在 WC-RGO 插层复合物组装过程中, 硫艮既作为错定及诱导剂, 又是制备片层二硫化铇 $\left(\mathrm{WS}_{2}\right)$ 的硫源. 材料具体制备方法如下: 首先利用浸渍法, 将偏铇酸根阴离子 $\left(\left[\mathrm{H}_{2} \mathrm{~W}_{12} \mathrm{O}_{40}\right]^{6-}\right)$ 牵引到 $\left(\mathrm{NH}_{2}\right)_{2} \mathrm{CS}$ 改性过的 $\mathrm{GO}$ 上形 成 $\left[\mathrm{H}_{2} \mathrm{~W}_{12} \mathrm{O}_{40}\right]^{6-}-\left(\mathrm{NH}_{2}\right)_{2} \mathrm{CS}-\mathrm{GO}$ 前驱体; 然后将前驱体放入管式炉中还原碳化, 前驱体先反应生成 $\mathrm{WS}_{2}$; 由于 $\mathrm{WS}_{2}$ 自身的 2D 片层结构, 反应中可以得到 $\mathrm{WS}_{2}-\mathrm{RGO}$ 插层复合物, 接着原位碳化生成 WC-RGO 插层复合物. 碳化铇-石墨烯负载铂电 催化剂 (Pt/WC-RGO) 通过微波辅助法制得, 并采用 $\mathrm{X}$ 射线衍射、扫描电子显微镜、透射电子显微镜及激光拉曼光谱等手 段对其结构与形貌进行了表征. 结果显示, 在 WC-RGO 插层复合物中, WC 的平均粒径为 $1.5 \mathrm{~nm}, \mathrm{RGO}$ 的层数约为 5 层. 在甲醇电氧化反应中, 相比于商用 Pt/C 催化剂, Pt/WC-RGO 插层复合物催化剂具有更高的电化学活性面积 (ECSA) 和较 高的峰电流密度 $\left(246.1 \mathrm{~m}^{2} / \mathrm{g} \mathrm{Pt}, 1364.7 \mathrm{~mA} / \mathrm{mg}\right.$ Pt), 分别是 Pt/C 的 3.66 和 4.77 倍. 我们分别利用 CO 溶出伏安法、计时电 流法及加速耐久性试验法验证了 Pt/WC-RGO 催化剂优秀的抗 CO 中毒能力及稳定性. Pt/WC-RGO 催化剂特殊的插层结 构, 在增加 WC 与 Pt 接触机会以加强协同作用的同时, 促进了催化过程中质量及电荷的转移, 因而具有比 Pt/C 更高的催化 活性. 可见, 通过制备WC-RGO插层复合物可降低 Pt 用量, 从而大大地降低燃料电池中电催化剂的成本. 同时, 我们使用 的是一种高效, 可大批量生产纳米材料的方法, 有助于催化剂的商业化.

关键词: 碳化铇-石墨烯; 插层复合物; 硫䐁; 针定; 甲醇氧化

收稿日期: 2016-06-08. 接受日期: 2016-08-25. 出版日期: 2016-11-05.

*通讯联系人. 电话/传真: (0571)88320830; 电子信箱：science@zjut.edu.cn

基金来源：中国国际科技合作项目 (2010DFB63680); 国家自然科学基金 (21376220); 浙江省自然科学基金 (LY16B060009, LY12B03008).

本文的英文电子版由Elsevier出版社在ScienceDirect上出版(http://www.sciencedirect.com/science/journal/18722067). 